\title{
GRAMMAR STRUCTURES WITH PRECEDENT PHENOMENA IN CONTEMPORARY AMERICAN YOUTH DISCOURSE
}

\section{V. Zolotarev}

Mikhail V. Zolotarev, https://orcid.org/0000-0002-1209-4750, Saratov State University, 83, Astrakhanskaya Str., Saratov, 410012, Russia, mizrkb@gmail.com

Analyzing the results of a linguistic experiment, this article investigates the usage patterns of precedent phenomena in the discourse of American young adults. The findings indicate that there are two major grammar models for the speakers to utilize precedent phenomena: comparative constructions and noun phrase complements. These patterns reveal some unique characteristics of the language units of interest.

Key words: precedent phenomena, American youth discourse, grammar structures, indirect nomination, young adults.

\section{Грамматические структуры с прецедентными фено- менами в современном американском молодежном дискурсе}

\section{М. В. Золотарев}

Золотарев Михаил Владимирович, кандидат филологических наук, доцент кафедры английского языка и методики его преподавания, Саратовский национальный исследовательский государственный университет имени Н. Г. Чернышевского, mizrkb@ gmail.com

Опираясь на результаты лингвистического эксперимента, автор статьи исследует модели употребления прецедентных феноменов в американском молодежном дискурсе. Проведенный анализ показал, что существует две основные грамматические модели употребления прецедентных феноменов в речи носителей языка: сравнительные обороты и дополнение. Распространенность данных моделей раскрывает некоторые особенности прецедентных феноменов.

Ключевые слова: прецедентные феномены, американский молодежный дискурс, грамматические структуры, непрямая номинация, молодежь.

\section{DOl: https://doi.org/10.18500/1817-7115-2018-18-4-376-380}

While conversing, language users tend to exploit their social, educational, literary, cultural, religious and the list may go on - backgrounds. They may allude to their knowledge with the help of unique language units that in the Russian linguistic tradition are called precedent phenomena. In general, precedent phenomena comprise various texts, facts, and names that language users have ever come across within their individual development and marked as important due to various reasons. Precedent phenomena usually refer to the previous experience of language users that they exploit while accomplishing various tasks in the process of communication. In other words, speak-

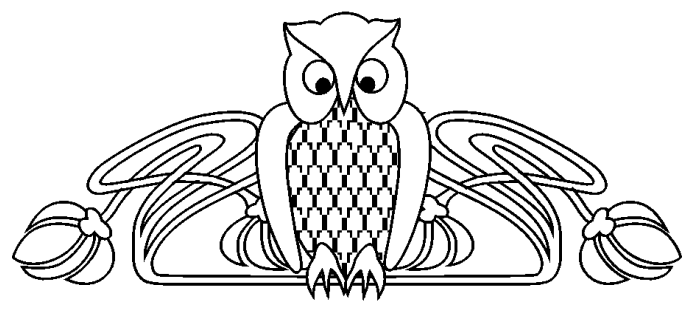

ers make use of their past experience in the form of precedent phenomena to meet the objectives of the ongoing communication. Failure to understand these references may result in a communication breakdown.

Precedent phenomena have been thoroughly investigated by Russian linguists since the late 1980s, when the term was first suggested. Admittedly, this term is not widely known outside Russia; however, the notion has been researched by several Western scholars with regard to cultural and literary references or allusions (see the works by Z. Ben-Porat, B. Hatim, and $\mathrm{R}$. Leppihalme ${ }^{1}$ ). The main research questions in many scholarly works dedicated to precedent phenomena usually boil down to one of the following groups: a) sources of precedent phenomena in various types of discourses and literary works; $b$ ) functions of precedent phenomena in various types of discourses and literary works; c) precedent phenomena and challenges of cross-cultural communication; d) precedent phenomena as stylistic devices in literary texts. Comparatively recent research works are conducted by cognitive scientists in an attempt to answer the question of how precedent phenomena reflect the cognitive processes of thinking (see the works by I. V. Privalova and S. P. Stepanov²).

Relatively little research attention is paid to the study of pure linguistic properties of precedent phenomena such as grammar and lexical patterns of their use in everyday communication. Therefore, my research aimed to explore the utilization of precedent phenomena in the discourse of young adults in the United States in terms of grammar and lexical contexts of their use. By scrutinizing the patterns of precedent phenomena usage, the analysis revealed some internal characteristics of these culture-specific language units.

Data were collected primarily during a linguistic experiment over a 16-month time span between February 2014 and July 2015 on a sample of speakers of American English aged 18-30. As a result of the experiment, I was able to collect a unique body of texts containing precedent phenomena, which allowed me to analyze the grammar patterns of their use.

The experiment comprised several stages. To begin with, I had to identify the sources of precedent phenomena relevant to American young adults. I suggest that the degree of relevance may be linked to the frequency rate of precedent phenomenon mentions in an Internet search engine such as Google. Having completed several searches, I concluded that the most frequently mentioned precedent phenomena come from one of the following sources: a) pop mu- 
sic; b) literature, c) the Bible; d) cinema; e) Greek mythology; f) paintings. Based on the Google search results, I chose several sentences containing precedent phenomena of those sources. The sentences were presented to a focus group of 10 American students aged 19-25 to check the relevance of the chosen language sample. The results of such pretest showed that the precedent phenomena that came from such a source as painting were not quite relevant for the focus group as most of the interviewees were not able to identify the sample and its source. Hence, I excluded this source as a subject matter from my further analysis. In addition, I had to exclude the Greek myths precedent phenomena due to the goals of a broader research work that was meant to be conducted on the same language sample and investigated the difference in the use of precedent phenomena in English and in Russian, and the Greek myths precedent phenomena fail to reflect the peculiarities of the languages of interest as they source from another language (see the work by M. V. Zolotarev ${ }^{3}$ ).

At the second stage of the linguistic experiment, I created an online questionnaire that contained 10 stimuli, precedent phenomena for which came from the following sources: a) pop music; b) literature; c) the Bible; d) cinema; e) television. The choice of the precedent phenomena for the questionnaire was determined by the same logic: The precedent phenomena most frequently mentioned in Google should be most relevant for the respondents. See Table 1 for the list of precedent phenomena I chose for the questionnaire.

Precedent Phenomena Selected for Questionnaire

\begin{tabular}{|l|c|}
\hline \multicolumn{1}{|c|}{ Precedent Phenomenon } & Number of Mentions \\
\hline Tom Sawyer & $23,700,000$ \\
\hline The Scarlet Letter & $8,360,000$ \\
\hline Adam and Eve & $47,300,000$ \\
\hline The Great Flood & $14,000,000$ \\
\hline Eminem & $94,900,000$ \\
\hline To come in like a wrecking ball & $4,710,000$ \\
\hline James Bond & $149,000,000$ \\
\hline The Hunger Games & $55,500,000$ \\
\hline Jon Stewart & $51,100,000$ \\
\hline The Oscars & $48,700,000$ \\
\hline
\end{tabular}

The respondents were first shown various sentences that contained precedent phenomena as examples for the given task. They were then asked to make up their own sentences that would contain the suggested precedent phenomena.

I asked 100 American respondents (aged 18-30) to complete the questionnaire and received 292 responses; 114 responses were not valid for the goals of the research and thus were excluded from the further analysis, which means that 178 responses constituting short texts containing the precedent phenomena met the experiment requirements. The collected language sample was further analyzed to identify frequent grammar patterns of the precedent phenomena usage.

The undertaken analysis revealed two major patterns of the precedent phenomena use in the speakers' discourse. Overall, precedent phenomena were utilized either as a part of a comparative construction (34\% of all uses) or as a noun phrase complement $(32 \%)$. It also should be mentioned that quite often the respondents used a certain type of precedent phenomena - precedent sayings - which make up an utterance and have a grammatical structure of their own (these sayings constituted $21 \%$ of all uses; the remaining $13 \%$ constituted other grammar patterns that will be discussed below). Compare the following examples:

(1) My name is Doe. John Doe.

(2) We're off to a fresh new start, like Noah after the Great Flood.

Example 1 is a paraphrase of a famous saying of Agent 007 and was constructed as a response to the stimulus James Bond. This reference to the precedent film is possible only if the grammatical structure of the original saying is preserved. Therefore, I omitted instances like that from my research because I was interested in the ways how a singular precedent phenomenon can be embedded in a sentence by the speakers. An instance of such a use is provided in Example 2, where the speaker refers to the Biblical text in order to better explain their point.

A closer analysis of the precedent phenomena use identified several tendencies. An interesting observation was made when the collected data were divided according to the time the precedent phenomenon has been around in the discourse of the speakers. More specifically, the usage patterns of "old" (Biblical and literary) and "new" (the ones that come from pop music, cinema, and television) precedent phenomena revealed a great imbalance between the two major patterns - comparative constructions and noun phrase complements. More specifically, the use of "old" precedent phenomena as comparative constructions constitutes $25 \%$ (counted separately for the uses of "old" precedent phenomena only) versus $43 \%$ for the "new" precedent phenomena used as comparative constructions. In addition, 53\% of the "old" precedent phenomena were used as noun complements, while only $11 \%$ of the "new" precedent phenomena were used as noun complements. The remaining 22 and $46 \%$ for the "old" and "new" precedent phenomena, respectively, constituted other usage patterns such as a subject of a sentence, an adverbial modifier, an address, etc.

Thus, the precedent phenomena that originated from such sources as the Bible and literature were more often used as noun phrase complements, while the precedent phenomena that originated from pop culture were utilized as a part of comparative constructions:

(3) After the politician's sex scandal was uncovered, he might as well have been branded with a 
scarlet $\boldsymbol{A}$-nobody wanted to be associated with him.

(4) Like a 19th-century Eminem, he scandalized the older generation of poets and galvanized what was seen as a crass subculture.

Example 3 above has a reference to N. Hawthorne's book The Scarlet Letter, while Example 4 alludes to the famous American rapper. In Example 3 , the precedent phenomenon is used as the object of the preposition with; however, in Example 4 the precedent name is a part of a comparative construction introduced with the preposition like. In my view, precedent phenomena have a tendency to assimilate in the discourse of the speakers and start being utilized more freely in sentences. Sometimes one can notice certain precedent phenomena functioning as noun phrase complements of specific verbs. Taken together, they manage to render precisely the precedent image:

(5) You might as well wear a red letter on your shirt with those slutty clothes you have on.

(6) If it doesn't stop raining, we better get to making an arc...

Examples 5 and 6 illustrate the verbs most frequently used to join precedent phenomena as direct objects with the references for such precedent texts as the novel The Scarlet Letter and the Biblical story of the Great Flood, respectively.

Even though the grammar pattern of a noun phrase complement predominates in the use of "old" precedent phenomena, the overall use of precedent phenomena investigated in this study gravitates toward the pattern of comparative constructions. Most often such constructions are introduced with the prepositions like or as:

(7) When the bus comes and there's clearly not enough room for everyone to sit, I suddenly feel like Katniss trying to reach the Cornucopia in time.

(8) I tell you, he was about as befuddled as Adam when he first laid eyes on Eve. I thought sure he'd faint, but all he did was stare.

Example 7 shows the use of the precedent phenomenon that alludes to the famous Hollywood movie The Hunger Games, while Example 8 refers to the Bible.

Beside the abovementioned prepositions, the comparative constructions with precedent phenomena may be introduced with the help of conjunctions such as than, as if, and so ... (that):

(9) Mom, you may not have been perfect, but you were better than Eminem's.

(10) She was dressed to the nines-as if she was about to be on the red carpet!
(11) Your acting was so phenomenal [that] I'll be waiting to see what you win at The Oscars.

As noted previously, precedent phenomena were also often used as nominal subject complements in the predicates. However, this grammar structure can also be treated as a comparative construction:

(12) Everyone was looking at my dirty shirt like I was Hester Prynne.

In this example, the precedent name Hester Prynne is used as a predicative and compares the speaker to the fictional character based on their similarity: Both were judged by the society.

The tendency to use precedent phenomena as a part of a comparative construction was so strong that even though a precedent phenomenon was technically used as an object of the preposition, sometimes the function of the comparison was activated:

(13) He seized upon it with all the glee of Jon Stewart seizing upon the latest Republican misdeed.

In this example, the quality of the person discussed in the sentence is compared with the quality of the famous comedian and television host Jon Stewart. Using precise grammatical terms, the precedent name is used as an object of the preposition of that fulfills the function of the genitive case, showing the relations between two characters based on their similarity.

In some rare instances, a precedent phenomenon was used as a subject of a sentence (Once we learned that it was possible to assassinate world leaders, we lost the old-fashioned, honourable approach to war, and Eden was forever lost to us), or as an address (You do your own work, Sawyer. I won't paint your fences for you), or even as an object complement (I couldn't decide who I wanted to spend time with, so I made them Hunger Games it for my attention). However, these instances were quite rare and could not be grouped as a stable usage pattern.

See Table 2 for the distribution of the grammar structures with precedent phenomena revealed in the linguistic experiment.

In sum, the conducted analysis showed that the most frequent usage pattern for the precedent phenomena in the sample was a comparative construction. Noun phrase complement was the second most common pattern. When the data were divided based on the criterion of the time the precedent phenomenon has been utilized in American discourse, the "old" precedent phenomena tended to be used more frequently as noun phrase complements while the "new" precedent phenomena were more often used as parts of comparative constructions.

Table 2

Distribution of Grammar Structures with Precedent Phenomena Revealed in Linguistic Experiment, \%

\begin{tabular}{|l|c|c|c|c|}
\hline \multicolumn{1}{|c|}{ Pattern type } & \multirow{2}{|c|}{$\begin{array}{c}\text { Comparison } \\
\text { construction }\end{array}$} & $\begin{array}{c}\text { Noun phrase } \\
\text { complement }\end{array}$ & $\begin{array}{c}\text { Precedent sayings (omitted } \\
\text { from the analysis) }\end{array}$ & Other patterns \\
\hline For the total number of instances & 34 & 32 & 21 & 13 \\
\hline For the "old" precedent phenomena & 25 & 53 & 4 & 18 \\
\hline For the "new" precedent phenomena & 43 & 11 & 37 & 9 \\
\hline
\end{tabular}




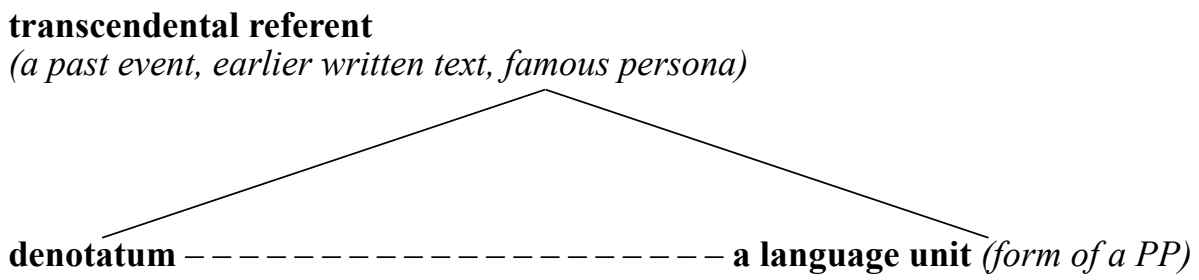

Fig. 1. Precedent Phenomenon Used to Name Denotatum

It seems to me that these tendencies may be explained if they are looked at as a reflection of internal characteristics of precedent phenomena that should be regarded as completely unique language units. As any language unit, precedent phenomena are able to fulfill the function of naming while used in the speech. However, they do this in a quite unique way. A precedent phenomenon (PP) a priori refers to an earlier written text, to an event of the past, or simply to an individual known within a certain language community. Figure demonstrates how such reference contributes to the process of naming.

Figure 1 shows the process of naming a denotatum with the help of a precedent phenomenon. When used in the discourse, the language unit that constitutes the form of a precedent phenomenon conveys the meaning through the reference to a transcendental referent, which appears to be a "fraction" of the past experience (e.g., the text of War and Peace, the legend of Ivan Susanin, etc.) and is not present in the situation of real communication. Alluding to a transcendental referent, the language unit is filled up with the meaning to name a denotatum, i.e., a number of actually existing objects that may be named by this unit. It is worth mentioning that the language form of a precedent phenomenon does not always possess the precedent characteristics, such as an ability to allude to the past experience. For example, the proper name Tom Sawyer may be defined as a precedent name only in a certain context: (14) Her favorite character is Tom Sawyer because he is as adventurous as she. (15) You look like Tom Sawyer with your river boat and farmer's hat. In Example 14, the proper name is not a precedent phenomenon as it just names the book character and singles out one of his features. In Example 15, Tom Sawyer is used to name a real person who visually reminds of the book character; however, the interlocutors should be acquainted with the precedential text of Mark Twain's book to understand the similarity. Thus, in Example 15 one can observe the unique process of naming illustrated in Figure 1.

Overall, the inner structure of a precedent phenomenon as a semiotic sign embodies dual characteristics: A precedent phenomenon may possess a rigid form of expression, which in certain contexts demonstrates the precedent characteristics, but in others it may function, for example, as a simple proper name. The reference to the past experience is usually built around similar features of the objects of present and past realities or, as in the case with Tom Sawyer, of the fictional reality. Hence, the utilization of precedent phenomena as parts of comparative constructions seems rather natural for these language constructs. In addition, the fact that comparative constructions got the highest percentage among the grammar patterns seems to speak in favor of this hypothesis.

Furthermore, I argue that the meanings of precedent phenomena are rather fluid. Therefore, it is very hard to discuss only one main meaning the precedent phenomenon can denote while used in the discourse. In fact, one and the same precedent phenomenon may denote various notions depending on the context. For example, in a number of contexts the reference to the novel The Adventures of Tom Sawyer may be built around such traits of the main character as cunning, idleness, bravery, and recklessness, or just around his appearance. And in various contexts, the precedent name Tom Sawyer may function as an epitome for all these features, thus denoting various notions. However, when the precedent phenomenon is widely utilized by the speakers within a longer period of time, it starts accumulating certain meanings and discards others; this allows the speakers to use the precedent phenomenon more freely in a sentence. Therefore, an "old" precedent phenomenon may be used as a noun phrase complement that can function in a number of different ways - for example, as a direct object or an adverbial prepositional phrase.

In conclusion, this study is an attempt to investigate some pure linguistic properties of precedent phenomena and their use in the contemporary discourse of the American youth. The results of this study related to grammar patterns of the precedent phenomena use suggest that the language constructs under discussion possess some unique qualities that single them out among other language units.

\section{References}

1 See: Ben-Porat $Z$. The poetics of literary allusions. In: PTL 1. 1978. P. 105-128; Hatim B. Intertextual intrusions: Towards a framework for harnessing the power of the absent text in translation. In: Translating sensitive texts: Linguistic aspects / ed. by K. Simms. Amsterdam; Rodopi, 1997. P. 29-45; Leppihalme R. Culture bumps: An empirical approach to the translation of allusions. Clevedon: Multilingual Matters Ltd., 1997. 
2 See: Privalova I. Yazykovoe soznanie: etnokul'tyrnaia markirovannost' (teoretiko-eksperimental'noe issledovanie) [Language awareness: ethnic and cultural marking (theoretical-experimental study)]. Diss. Dr. Sci. (Phil.). Moscow, 2006 (in Russian); Stepaniv E. Participation of a precedent name in the process of conceptual blending. Vestnik Yuzhno-Ural'skogo gosudarstvennogo universiteta. Ser. Lingvistika [Bulletin of the South Ural State University.
Ser. Linguistics], 2017, vol. 14, no. 1, pp. 72-76 (in Russian).

3 Zolotariov M. Lingvopragmaticheskie osobennosti pretsedentnykh fenomenov $v$ sovremennom molodiozhnom diskurse (na materiale angliiskogo I russkogo yazykov) [Linguistic and pragmatic features of precedent phenomena in modern youth discourse (by the material of English and Russian languages)]. Thesis Diss. Cand. Sci. (Phil.). Saratov, 2017 (in Russian).

\section{Cite this article as:}

Zolotarev M. V. Grammar Structures with Precedent Phenomena in Contemporary American Youth Discourse. Izv. Saratov Univ. (N. S.), Ser. Philology. Journalism, 2018, vol. 18, iss. 4, pp. 376-380. DOI: https://doi.org/10.18500/1817-7115-2018-18-4-376-380

\section{Образец для цитирования:}

Zolotarev M. V. Grammar Structures with Precedent Phenomena in Contemporary American Youth Discourse [Золотарев М. В. Грамматические структуры с прецедентными феноменами в современном американском молодежном дискурсе] // Изв. Сарат. ун-та. Нов. сер. Сер. Филология. Журналистика. 2018. Т. 18, вып. 4. С. 376-380. DOI: https://doi.org/10.18500/18177115-2018-18-4-376-380 